\title{
The Ability of Digital Literacy for Elementary School Teachers
}

\author{
Berliana Hutagalung $^{1^{*}}$, Widyastuti Purbani ${ }^{2}$ \\ 1,2 Universitas Negeri Yogyakarta, Yogyakarta, Indoensia \\ *e-mail: berlianahutagalung.2019@student.uny.ac.id
}

\begin{abstract}
This study aims to analyze the digital literacy skills of elementary school teachers. This study used quantitative research. The research subjects were 76 elementary school teachers. The research instruments used were observation sheets, interview guides, and questionnaires. The data analysis technique used in this research is a descriptive statistical analysis which is carried out by providing an overview of the data that has been collected and then making conclusions or descriptions related to the data. Based on the results of this study, it can be seen that the digital literacy skills of elementary school teachers need to be improved. This is done so that elementary school teachers can have good literacy skills in using and utilizing existing technology tools and digital media to design or design learning processes that are creative, innovative, and fun and can make students think critically. Also, good digital literacy skills can help teachers respond to the challenges of the times related to the application of mixed learning models in the world of education. A good teacher's digital literacy skills can help teachers transform learning so that it is more creative, innovative. Also, teachers can answer the challenges of the times related to the application of blended learning. A teacher who has good digital literacy skills shows that the teacher has a desire to continue to learn and develop his professional teaching.
\end{abstract}

Keywords: Digital Literacy, Elementary School Teachers, Digital Technology

\section{Introduction}

Advances in technology and information affect all aspects of human life, including education. Education in various parts of the world has undergone fundamental changes in the era of globalization. There are many advances in science and technology that can be enjoyed (Sailer et al., 2021; Yilmaz \& Goktas, 2017). Various kinds of teaching material sources, digital learning media are available on the internet and can be used freely, anytime, and anywhere (Azubuike et al., 2021; Bakri et al., 2016). Technological advances have provided various kinds of tools to increase the effectiveness of the learning process (Boyd, 2019; Unwin, 2019; Warden et al., 2020). This technological advancement indirectly requires teachers to be able to develop their quality so that they can maximize learning in the $21 \mathrm{st}$ century.

In the 21st century technology and information are developing very rapidly. The 21 st century brings about many very rapid changes (Binkley et al., 2012; Popkova et al., 2019; Rusdin, 2018). These changes can provide good opportunities if used properly and have the ability to use technology. However, this change can also be a big problem if it is not properly utilized and the ability to use technology is not available (Gustavo, 2010; Zain, 2017). Educational institutions are currently competing to meet needs by producing quality students. This of course is done through a good and quality education process as well. If the quality of education is low, it will lower people's lives. The implementation of a relevant and quality education system is a determining factor for our success in educating the nation's life and advancing national culture (Bedir, 2019; Chai \& Kong, 2017; Daggol, 2017). Therefore education and the learning process must be regulated appropriately according to the needs of the community. Learning in the 21st century is expected to be carried out with the support of the application of media and various digital technologies or better known as Blended Learning (Gelen Assoc, 2018; Lavi et al., 2021).

\footnotetext{
${ }^{*}$ Corresponding author.
}

Received March 07, 2021; Accepted October 31, 2021; Available online December 25, 2021 This is an open access article under the CC BY-SA license. Copyright $(2021$ by Author. Published by Universitas Pendidikan Ganesha 
Blended learning is an integrated blend of traditional learning with online web-based learning (Akhmalia et al., 2018; Yigzaw et al., 2019). Blended learning is very effective to be applied in schools. This is due to the rapid development of technology that creates many new things that attract students' attention and also beat conventional learning models. Students are more interested in learning using media or learning models related to technology compared to learning with conventional learning models, such as lectures (Bock et al., 2018; Maarop \& Embi, 2016). Blended learning can run well if an educator has good digital literacy skills. Digital literacy skills in question are skills in using or utilizing technological tools and other digital media to support the learning process (Beck et al., 2021; Helsper \& Shamed, 2019; Liang et al., 2021). This skill is very important for an educator to have so that the learning process carried out can be modified with technological developments by the times.

The phenomenon of the Covid-19 outbreak in 2020 led the government to issue several policies including social distancing, physical distancing, to large-scale social restrictions (PSBB) (Ali et al., 2021; Rafique et al., 2021). The covid-19 phenomenon requires teachers to have adequate digital literacy to teach online and apply the latest and innovative educational models (Beck et al., 2021; Sánchez-Cruzado et al., 2021). In addition, teachers' digital literacy skills also allow teachers to adapt to new learning models, namely blended learning. The blended learning model helps educational institutions, especially teachers, respond to policies issued by the government regarding the prevention of the spread of the coronavirus (Bervell et al., 2020; Siripongdee et al., 2020). The learning process can be done online by taking advantage of technological advances.

Interviews conducted with the Deputy Principal of SD Inpres 51 Ambon, Mrs. Betty Tahamata, stated that during the coronavirus pandemic teachers had difficulty carrying out the learning process online, especially the use of zoom media in teaching or face-to-face with students online. In addition, the use of applications for tests or exams or quizzes is to see the level of student understanding of the material provided, such as Google forms, Kahoot, quiz. This is because the teachers still do not understand deeply the use of digital media so that the learning that has been carried out online is only one way. This means that the teacher only sends learning material to students and then students learn independently in their respective homes. In addition, the implementation of exams or tests is not carried out online but is carried out offline, the teacher gathers several students whose homes are close together and then tests or exams are carried out. The results of interviews conducted with several elementary school teachers stated that elementary school teachers had difficulty using digital media and technological tools to carry out the learning process online. This resulted in online learning not running optimally. Digital literacy skills are very beneficial for every individual in improving their performance and professionalism at work (Kurnia \& Astuti, 2017; Masitoh, 2018; Rastati, 2018).

Digital literacy is one of the abilities that every individual must-have. Digital literacy skills can create a society with a critical and creative mindset and perspective (Helsper \& Shamed, 2019; Liza \& Andriyanti, 2020; Suni Astini, 2020). The concept of digital literacy can be used as a measure of the quality of students' work in a digital environment and provides scientists and developers with more effective means of communication in designing useroriented environments (Liza \& Andriyanti, 2020; McDougall \& Potter, 2019). Many benefits can be obtained through digital literacy, for example, getting information more quickly and easily, uploading students' work on social media, and doing questions online. Students can easily find information, one of which is through the website page www.google.com. Also, various types of applications that can help teachers and students in learning include: google classroom, google form, and so on. Learning resources are not only limited to printed materials, but also digital materials and media that can be used practically and more efficiently. So that online learning can be done anywhere and anytime. Digital literacy does not only add technology to the learning process but also to improve the quality of learning (Rafique et al., 2021; Tang et al., 2021).

The results showed that literacy training involving teachers and elementary school students positively affected literacy awareness in the school environment (Hanik, 2020; Nahdi \& Jatisunda, 2020). Other studies also stated a relationship between the application of 
digital literacy and increased learning (Anggraeni et al., 2019; Desi, 2020; Kurnia \& Astuti, 2017). It can be concluded that digital literacy is very important to increase students' knowledge. This study aims to analyze the digital literacy skills of elementary school level teachers in the Kecamatan Baguala Ambon. It is hoped that digital literacy can increase students' knowledge and understanding so that it impacts increasing student learning outcomes.

\section{Method}

The type of research used is quantitative research with descriptive methods. The population in this study were elementary school teachers in the Kecamatan Baguala Ambon. The research subjects were 76 teachers. The research subjects were determined using the Slovin formula, then the simple random sampling technique was carried out. This research begins by finding the underlying problems expressed by facts, then formulating the problems that are formed in several research questions. After that, the researcher looks for a theory that is used to clarify and support the background of the problem. Furthermore, data collection was carried out using research instruments. Data collection in this study refers to the results of a digital literacy questionnaire given to the teacher. Furthermore, interviews and observations were conducted with several teachers who were randomly selected from the results of the questionnaire. Through the results of questionnaires, interviews, and observations, conclusions will be made about the digital literacy skills of elementary school teachers, the challenges, and what has been done to overcome these challenges. The instruments used in this study were interview sheets, teacher digital literacy questionnaires, and observations. The following grids of interview sheets and questionnaires used are presented in Table 1.

Table 1. Teacher interview grid

\begin{tabular}{llcc}
\hline No & \multicolumn{1}{c}{ Aspect } & Item Number & Total \\
\hline 1 & Number of digital literacy trainings attended by teachers & $1,2,3$ & 3 \\
2 & $\begin{array}{l}\text { The intensity of the application and use of digital literacy } \\
\text { in learning activities }\end{array}$ & $4,5,6,7,8,9$ & 6 \\
3 & $\begin{array}{l}\text { The level of understanding of teachers in using digital } \\
\text { media and the internet }\end{array}$ & $10,11,12,13$, & 6 \\
\hline & Numbers of item & $14,15,16$ & $\mathbf{1 5}$ \\
\hline & & (Nasrullah et al., 2017)
\end{tabular}

Interviews were conducted with several elementary school teachers in Baguala Ambon District to determine the digital literacy skills of teachers and supporting and inhibiting factors in implementing digital literacy in the learning process. The results of the interview will be used to describe the digital literacy skills of teachers as well as the inhibiting and supporting factors. The following grid of interview sheets is presented in Table 2.

Table 2. Observation guideline sheet

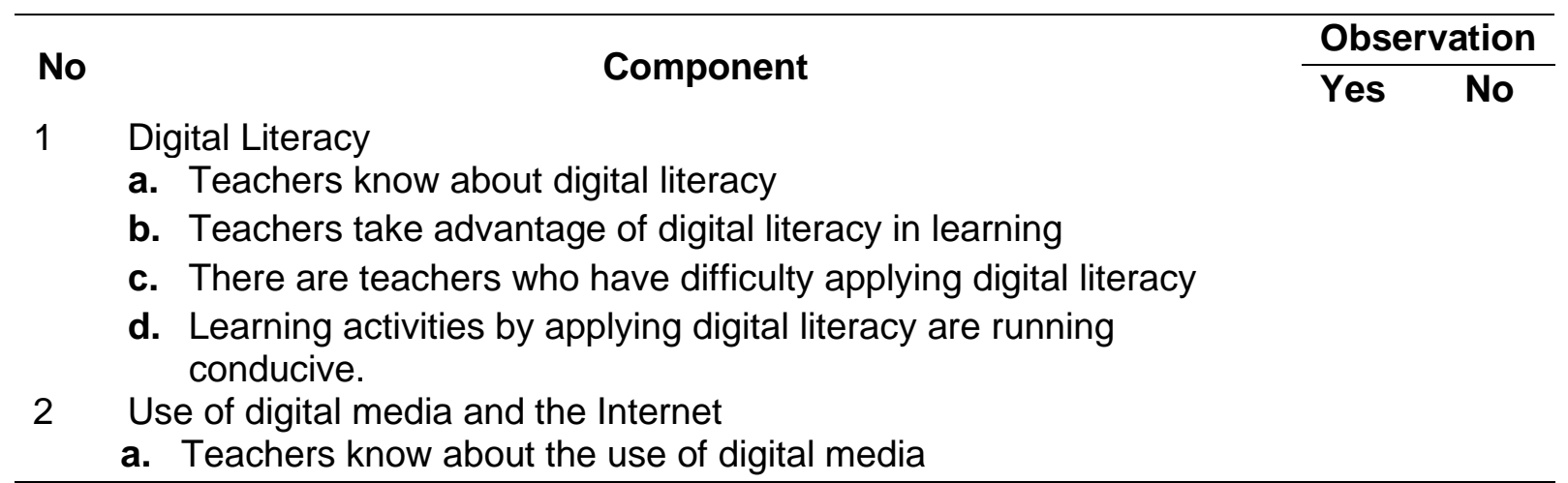


No

Component

Observation

Yes No

b. Teachers know about internet usage

c. The teacher delivers or provides learning materials to students using digital media and the internet

d. Digital media and the internet help teachers do online learning

e. There are teachers who have difficulty using digital media and the internet.

(Nasrullah et al., 2017)

Observations are used to determine the extent of the digital literacy skills of elementary school level teachers. The following grid of observation sheets is presented in Table 3.

Table 3. Teacher's Digital Literacy Questionnaire Grid

\begin{tabular}{llll}
\hline No & Indicator & Item Number & Total \\
\hline 1 & Experience using digital media in teaching & $1,2,3$ & 3 \\
2 & $\begin{array}{l}\text { Accessing information from the internet in the teaching and } \\
\text { learning process }\end{array}$ & $4,5,6,7$ & 4 \\
3 & Digital-based activities and materials used in learning & $8,9,10,11,12$, & 8 \\
& & $13,14,15$ & 2 \\
4 & $\begin{array}{l}\text { Barriers to the use of digital media in the teaching and } \\
\text { learning process }\end{array}$ & 16,17 & 3 \\
\hline & The teacher's ability to use digital media & $18,19,20$ & 3 \\
\hline & Numbers of Item & $\mathbf{2 1}$ \\
\hline
\end{tabular}

(Nasrullah et al., 2017)

A digital literacy questionnaire was given to teachers to gather information about the implementation of digital literacy in schools, the obstacles faced by teachers, and the ability of teachers to apply digital literacy. The data analysis technique used in this research is a descriptive statistical analysis which is carried out by providing an overview of the data that has been collected then making conclusions or descriptions related to the data. The research questionnaire uses a Likert scale.

\section{Result and Discussion}

\section{Results}

The results showed that elementary school teachers in the Baguala District of Ambon had difficulty using and utilizing digital literacy in carrying out the learning process. This is by the results of interviews conducted with the Deputy Principal of SD Inpres 51 in Ambon, which stated that during the coronavirus pandemic teachers had difficulty carrying out the learning process online. This is because the teachers still do not have a deep understanding of the use of digital media so that the learning that has been carried out online is only one way. This means that the teacher only sends learning material to students and then the students learn independently in their respective homes. Also, the implementation of exams or tests is not carried out online but is carried out offline, where the teacher gathers several students whose homes are close together and then tests or exams are carried out.

The fourth-grade teacher at SDN 3 Ambon added that online learning was not optimal because most of the teachers were elderly so they had minimal knowledge related to how to use digital media and applications in learning. Also, no training is provided as a provision for doing online learning. The same thing was conveyed by one of the teachers at SDN 80 Ambon that before online learning was implemented, teachers rarely used digital media in 
the learning process. This is what makes teachers experience difficulty in carrying out the learning process online and also difficulties in conducting online assessments.

Based on the results of the interview above, it can be seen that there are several obstacles faced by teachers in implementing digital literacy in the online learning process, including (1) they do not understand in detail about the use of digital literacy. (2) some of the teachers are elderly, so they need time to be able to learn again about digital usage. (3) has minimal knowledge related to how to use digital media and learning applications. (4) there is no training provided as provisions for teachers in conducting online learning by utilizing digital media and technological tools. (5) Teachers rarely use digital media in the learning process before issuing online learning policies. In addition to interviews and observations, teacher digital literacy questionnaires were also distributed to 77 elementary school teachers. The questionnaire consists of 5 indicators and 21 questions. This questionnaire uses a Likert scale. One indicator of teacher digital literacy is the experience of teachers using digital media in teaching. The following is the quantitative data from indicator 1.

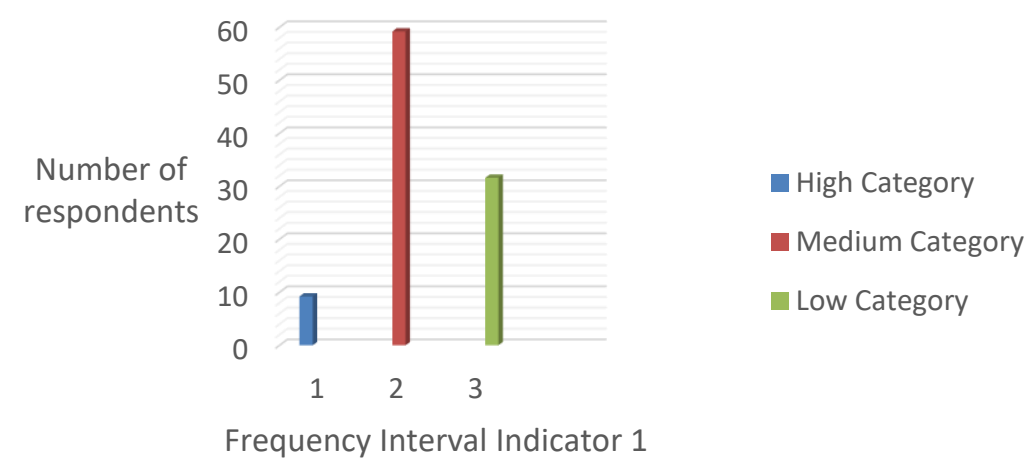

Figure 1. The results of the digital literacy questionnaire for teacher indicator 1

Based on Figure 1, it can be seen that of the 76 respondents, 7 teachers were in the high category, 45 were included in the medium category, and 24 teachers were included in the low category related to the experience of using digital media in teaching. The results show that $9.2 \%$ of teachers are in the high category, $59.2 \%$ of teachers are in the medium category, and $31.6 \%$ of teachers are in the low category. From the results of this percentage, it can be concluded that the experience of using digital media in teaching elementary school teachers in the Baguala District of Ambon is in the moderate category.

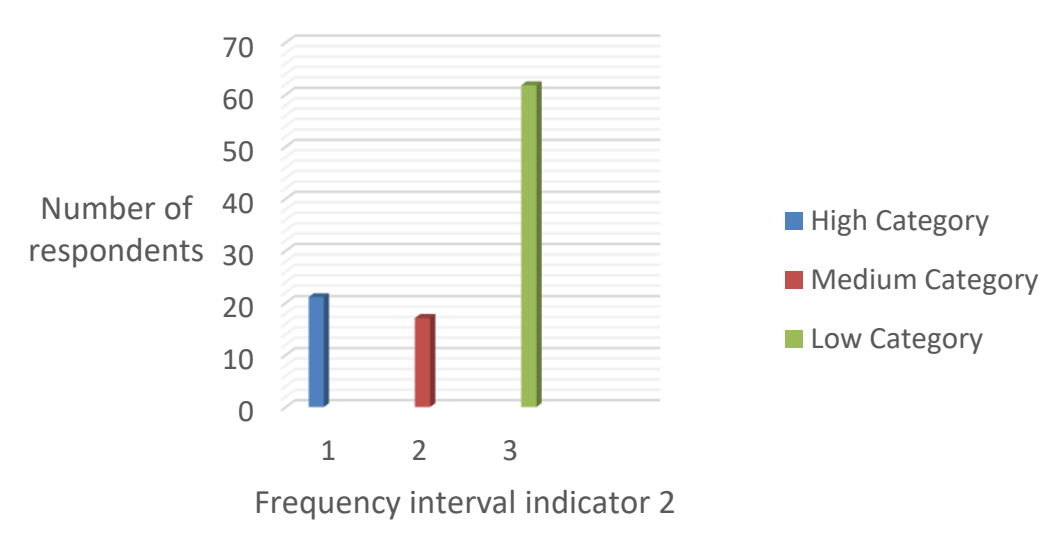

Figure 2. The results of the digital literacy questionnaire for the teacher indicator 2

The data in the diagram above shows the results of a questionnaire from indicators of accessing information from the internet in the teaching and learning process. The results of 
these data indicate that of the 76 teacher respondents, there are 16 teachers in the high category, 13 teachers in the medium category, and 47 teachers in the low category. If the frequency of the data is converted into a percentage, the results show that $21.1 \%$ of teachers are in the high category, $17.1 \%$ of teachers are in the medium category, and $61.8 \%$ are in the low category. From the results of this percentage, it can be concluded that the activities of accessing information from the internet in the teaching and learning process carried out by elementary school teachers in the Baguala District of Ambon are included in the low category.

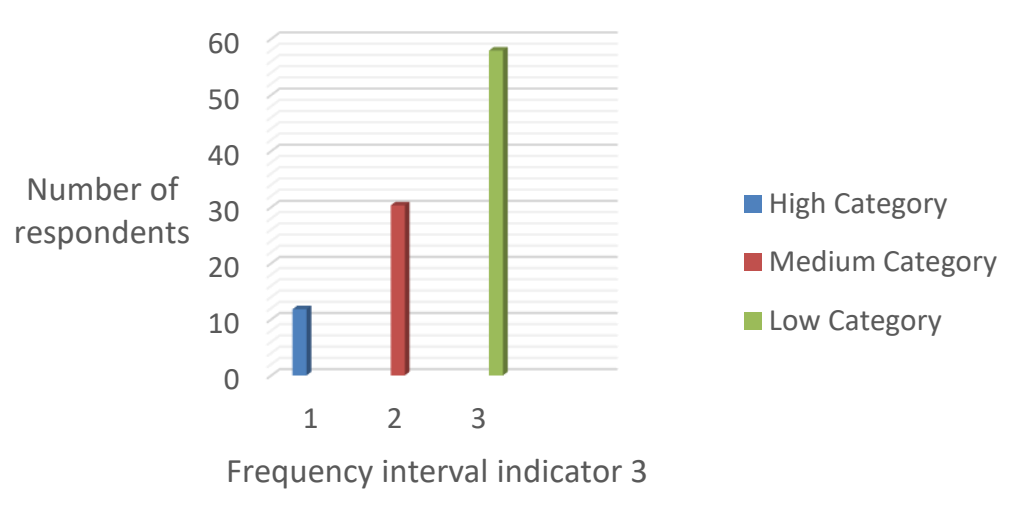

Figure 3. The results of the digital literacy questionnaire for the teacher indicator 3

Based on Figure 3, it can be seen that of the 76 respondents, 9 teachers were included in the high category, 23 teachers were included in the medium category, and 44 teachers were included in the low category. If the data is converted into a percentage, the results show that there are $11.8 \%$ of teachers in the high category, $30.3 \%$ of teachers in the medium category, and $57.9 \%$ of teachers in the low category. From this percentage, it can be concluded that most of the digital-based activities and materials used by teachers in learning are in the low category.

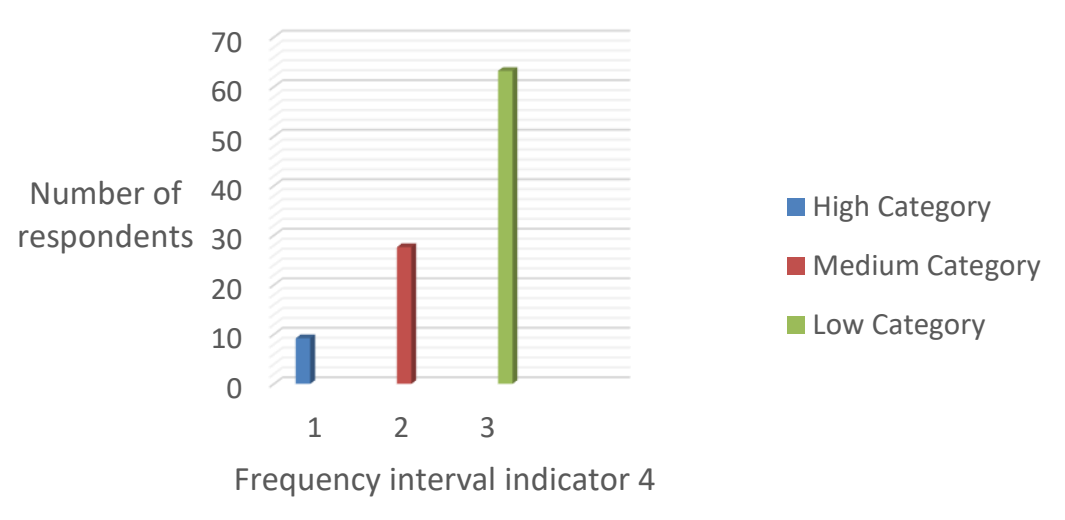

Figure 4. The results of the digital literacy questionnaire for the teacher indicator 4

Based on Figure 4, it can be seen that out of 76 primary school teacher respondents, 7 teachers were included in the high category, 21 teachers were included in the medium category, and 48 teachers were included in the low category. If the data is converted into a percentage, the results show that $9.2 \%$ of teachers are in the high category, $27.6 \%$ of teachers are in the medium category, and $63.2 \%$ of teachers are in the low category. From the results of this percentage, it can be concluded that the majority of elementary school teachers in the Baguala District of Ambon experience obstacles in the use of digital media in the teaching and learning process. 
The results of the teacher's digital literacy questionnaire from the indicators of the teachers' ability to use digital media. The results of the data show that of the 76 respondents, 17 teachers were included in the high category, 10 were included in the medium category, and 49 teachers were included in the low category. If the frequency of the data is converted into a percentage, the results show that $22.4 \%$ of teachers are in the high category, $13.2 \%$ are in the medium category, and $64.5 \%$ are in a low category. From this percentage, it can be concluded that most of the elementary school teachers in the Baguala District of Ambon have low abilities in using digital media.

\section{Discussion}

Indonesia has many regions and territories in 34 existing provinces. All regions and regions are not all developing equally, meaning that there are regions that have experienced technological developments and have even enjoyed good use of technology. However, on the other hand, some areas have accepted technology but do not have good knowledge to use and utilize existing technology (Ibad et al., 2020; Monitorir, 2020; Sari et al., 2021). Besides, some have not felt and enjoyed the use of technology at all. This of course has an impact on the development and progress in the world of education in existing regions and regions, one of which is in the Kecamatan Baguala Ambon. Based on the results of interviews, observations, and teacher digital literacy questionnaires, $64.5 \%$ of elementary school teachers in the Kecamatan Baguala Ambon are in a low category, meaning that most of the elementary school teachers in the Kecamatan Baguala Ambon have low abilities in using digital media. This resulted in teachers having difficulty responding to government policies to stop the spread of Covid-19 by learning online. Another factor that makes teachers difficult is that before the online learning policy was issued the teacher also very rarely used digital media in the learning process, this was evident from the results of the digital literacy questionnaire for teacher indicator 3 which stated that $57.9 \%$ of teachers were in a low category, meaning that most of the activities and materials digital-based teachers used in learning are in a low category. Digital literacy has become a remedy to be applied to schools to improve the quality of technology-based education and teaching, but there are still many schools, teachers, or students who have not used it (Hanik, 2020; Kurnia \& Astuti, 2017; Tomczyk, 2020).

The results of the research conducted showed that the digital literacy skills of elementary school teachers in the Kecamatan Baguala Ambon were classified as low, which made teachers have difficulty implementing online learning. This also has an impact on students, because students do not get learning material and also explain material related well so that student's understanding of the learning material that is carried out will be reduced. Several previous studies related to the application of digital literacy in education show that digital literacy skills are very important and have a positive impact on literacy awareness in the school environment (Agustini et al., 2020; Sadaf \& Johnson, 2017). Digital literacy has a positive impact on student skills that are essential for successful learning (Akhyar et al., 2021; Johnston, 2020; Masitoh, 2018). Digital literacy skills can help teachers improve their professionalism in teaching and educating students. Teachers can use digital literacy skills to access a wide variety of learning media that support and relate to learning materials using existing technology and digital media tools (Rizal et al., 2019; SánchezCruzado et al., 2021). Besides, the application of literacy also affects improving learning. This shows that digital literacy skills are very important for every individual (Park et al., 2020; Shepherd \& Henderson, 2019).

Teachers are expected to be able to use digital devices effectively and have digital literacy skills so that they can follow digital transformation (Anggraeni et al., 2019; Yildiz, 2020). This is because students who are taught today are students who were born in the era of globalization, technological tools are developing very rapidly and there are many applications or learning media that are fun and interesting for students to learn (Chassiakos et al., 2016; Sukarno \& Widdah, 2020). Thus, as a teacher, he must develop himself in using technological tools so that in the learning process the teacher can modify learning using existing digital media so that learning is more enjoyable and challenges students to be able 
to think critically and develop their abilities in the use of digital media. Good digital literacy skills can make teachers more critical in assessing content available online and paying attention to digital safety (Avello Martínez \& López Fernández, 2015; Purnama et al., 2021).

On the other hand, digital literacy skills also help in responding to the challenges of the times related to the application of blended learning in the world of education. Blended learning is a model that adapts learning and development to individual needs as well as innovative and technological advances with traditional learning in creating practical and meaningful teaching and learning activities for students and teachers (Morze et al., 2021; Norberg et al., 2011; Sutisna, 2016). Blended learning can help or facilitate students to learn using different learning methods or styles. Also, blended learning makes students search and find the information they want to know for themselves (Masitoh, 2018; Siregar \& Manurung, 2020). Thus students can become someone who is not only accepting but also exploring to find for themselves so that many experiences can be used as lessons for students. This makes students become lifelong learners (Effendi \& Hendriyani, 2020; Shepherd \& Henderson, 2019). The application of blended learning is related to digital literacy skills. This is because blended learning can run well if an educator has good digital literacy skills.

There have been many studies that have examined digital literacy skills, both those of teachers and students, the importance of digital literacy in the learning process, and so on (Effendi \& Hendriyani, 2020; Sadaf \& Johnson, 2017; Tomczyk, 2020). However, each research carried out has its own characteristics regarding digital literacy. This study focuses more on digital literacy skills possessed by elementary school teachers, especially in Baguala Ambon District. This research was conducted to reveal the abilities and difficulties experienced by elementary school teachers in Baguala Ambon District in implementing digital literacy. on direct experience in conducting this research, there are several limitations that future researchers have experienced and can pay attention to further refine their research. Several limitations in the study, among others; the researcher used a questionnaire to collect data. In the process, sometimes it does not show the respondent's true opinion, this is due to different assumptions and understandings and the honesty factor in filling out the questionnaire.

\section{Conclusions and Suggestions}

The results of the research conducted indicate that the digital literacy skills of elementary school teachers in Baguala Ambon District are low. Based on the results of this study, it can be seen that the digital literacy skills of elementary school teachers in Kecamatan Baguala Ambon need to be improved. This is done so that elementary school teachers in Kecamatan Baguala Ambon can have good literacy skills in using and utilizing existing technology tools and digital media to design or design learning processes that are creative, innovative, and fun and can make students think critically. Also, good digital literacy skills can help teachers respond to the challenges of the times related to the application of mixed learning models in the world of education. A good teacher's digital literacy skills can help teachers transform learning so that it is more creative, innovative.

\section{References}

Agustini, D., Lian, B., \& Sari, A. P. (2020). School'S Strategy for Teacher'S Professionalism Through Digital Literacy in the Industrial Revolution 4.0. International Journal of Educational Review, 2(2), 160-173. https://doi.org/10.33369/ijer.v2i2.10967.

Akhmalia, N. L., Suana, W., \& Maharta, N. (2018). Efektivitas Blended Learning Berbasis LMS dengan Model Pembelajaran Inkuiri pada Materi Fluida Statis terhadap Penguasaan Konsep Siswa. JIPFRI (Jurnal Inovasi Pendidikan Fisika Dan Riset Ilmiah), 2(2), 56-64. https://doi.org/10.30599/jipfri.v2i2.299.

Akhyar, Y., Syarif, M. I., Fitri, A., Simbolon, P., S, A. P., Tryana, N., \& Abidin, Z. (2021). Contribution of Digital Literacy to Students ' Science Learning Outcomes in Online 
Learning. International Journal of Elementary Education, 5(2), 284-290. https://doi.org/10.23887/ijee.v5i2.34423.

Ali, S. R. M., Mensi, W., Anik, K. I., Rahman, M., \& Kang, S. H. (2021). The impacts of COVID-19 crisis on spillovers between the oil and stock markets: Evidence from the largest oil importers and exporters. Economic Analysis and Policy. https://doi.org/10.1016/j.eap.2021.11.009.

Anggraeni, H., Fauziyah, Y., \& Fahyuni, E. F. (2019). Penguatan Blended Learning Berbasis Literasi Digital Dalam Menghadapi Era Revolusi Industri 4.0. Al-Idarah: Jurnal Kependidikan Islam, 9(2), 190-203. https://doi.org/10.24042/alidarah.v9i2.5168.

Avello Martínez, R., \& López Fernández, R. (2015). Digital literacy for teachers in Cuban Tourism and Hotel Management Schools. Some experiences on its development. RUSC. Universities and Knowledge Society Journal. https://doi.org/10.7238/rusc.v12i3.1994.

Azubuike, O. B., Adegboye, O., \& Quadri, H. (2021). Who gets to learn in a pandemic? Exploring the digital divide in remote learning during the COVID-19 pandemic in Nigeria. International Journal of Educational Research Open, 2-2. https://doi.org/10.1016/j.ijedro.2020.100022.

Bakri, F., Siahaan, B. Z., \& Permana, A. H. (2016). Rancangan Website Pembelajaran Terintegrasi dengan Modul Digital Fisika Menggunakan 3D PageFlip Professional. Jurnal Penelitian \& Pengembangan Pendidikan Fisika, 2(2), 113-118. https://doi.org/10.21009/1.02215.

Beck, E., Goin, M. E., Ho, A., Parks, A., \& Rowe, S. (2021). Critical digital literacy as method for teaching tactics of response to online surveillance and privacy erosion. Computers and Composition. https://doi.org/10.1016/j.compcom.2021.102654.

Bedir, H. (2019). Pre-service ELT teachers' beliefs and perceptions on 21st century learning and innovation skills (4Cs). Journal of Language and Linguistic Studies, 15(1), 231246. https://doi.org/10.17263/jls.547718.

Bervell, B., Nyagorme, P., \& Arkorful, V. (2020). LMS-Enabled Blended Learning Use Intentions among Distance Education Tutors: Examining the Mediation Role of Attitude Based on Technology-Related Stimulus-Response Theoretical Framework (TR-SR-TF). Contemporary Educational Technology, 12(2), ep273. https://doi.org/10.30935/cedtech/8317.

Binkley, M., Erstad, O., Herman, J., Raizen, S., Ripley, M., Miller-Ricci, M., \& Rumble, M. (2012). Assessment and teaching of 21st century skills. Springer Science+Business Media, 17-66. https://doi.org/10.1007/978-94-007-2324-5_2.

Bock, A., Modabber, A., Kniha, K., Lemos, M., Rafai, N., \& Hölzle, F. (2018). Blended learning modules for lectures on oral and maxillofacial surgery. British Journal of Oral and Maxillofacial Surgery, 56(10), 956-961. https://doi.org/10.1016/j.bjoms.2018.10.281.

Boyd, L. (2019). Using Technology-Enabled Learning Networks to Drive Module Improvements in the UK OpenUniversity. Journal of Interactive Media in Education, 2019(1), 1-7. https://doi.org/10.5334/jime.529.

Chai, C. S., \& Kong, S.-C. (2017). Professional learning for 21 st century education. Journal of Computers in Education, 4(1), 1-4. https://doi.org/10.1007/s40692-016-0069-y.

Chassiakos, Y. R., Radesky, J., Christakis, D., Moreno, M. A., Cross, C., Hill, D., Ameenuddin, N., Hutchinson, J., Boyd, R., Mendelson, R., Smith, J., \& Swanson, W. S. (2016). Children and adolescents and digital media. Pediatrics, 138(5). https://doi.org/10.1542/peds.2016-2593.

Daggol, G. D. (2017). Lifelong learning: Not a 21st century, but an omnitemporal skill. International Journal of Social Humanities Sciences Research (JSHSR), 4(12), 12541267. https://doi.org/10.26450/jshsr.207.

Desi, Y. P. (2020). Gerakan Literasi Digital Berbasis Sekolah: Implementasi dan Strategi. Jurnal IImu Komunikasi, 17(1), 51. https://doi.org/10.31315/jik.v17i1.3510. 
Effendi, H., \& Hendriyani, Y. (2020). The Conceptual and Hypothetical Model of Interactive Blended Problem Based Learning. JPI (Jurnal Pendidikan Indonesia), 8(2), 285. https://doi.org/10.23887/jpi-undiksha.v8i2.24162.

Gelen Assoc, I. (2018). Academicians' Predictions Of 21 St Century Education And Education In The 21 St Century. European Journal of Education Studies, 4, 165-204. https://doi.org/10.5281/zenodo.1233478.

Gustavo, N. S. (2010). A 21st-Century Approach to Health Tourism Spas: The Case of Portugal. Journal of Hospitality and Tourism Management, 17(1). https://doi.org/10.1375/jhtm.17.1.127.

Hanik, E. U. (2020). Self directed learning berbasis literasi digital pada masa pandemi covid19 di Madrasah Ibtidaiyah. ELEMENTARY: Islamic Teacher Journal, 8(1), 183. https://doi.org/10.21043/elementary.v8i1.7417.

Helsper, E. J., \& Shamed, D. (2019). Excessive internet use by young Europeans: psychological vulnerability and digital literacy? Information, Communication \& Society, 23(9), 1-19. https://doi.org/10.1080/1369118X.2018.1563203.

Ibad, W., Maghfiroh, L., Azza, M. I., Cahyani, S. A., \& Ulfayati, Z. A. (2020). Dampak Pandemi Covid-19 Terhadap Kegiatan Belajar. JIEES: Journal of Islamic Education at Elementary School JIEES, 10-16. https://doi.org/10.35760/psi.2020.v13i2.3572.

Johnston, N. (2020). The Shift towards Digital Literacy in Australian University Libraries: Developing a Digital Literacy Framework. Journal of the Australian Library and Information Association. https://doi.org/10.1080/24750158.2020.1712638.

Kurnia, N., \& Astuti, S. I. (2017). Peta Gerakan Literasi Digital Di Indonesia: Studi Tentang Pelaku, Ragam Kegiatan, Kelompok Sasaran Dan Mitra Yang Dilakukan Oleh Japelidi. Informasi, 47(2), 149. https://doi.org/10.21831/informasi.v47i2.16079.

Lavi, R., Tal, M., \& Dori, Y. J. (2021). Perceptions of STEM alumni and students on developing 21st century skills through methods of teaching and learning. Studies in Educational Evaluation, 70, 1-11. https://doi.org/10.1016/j.stueduc.2021.101002.

Liang, Q., Torre, J. de la, \& Law, N. (2021). Do background characteristics matter in Children's mastery of digital literacy? A cognitive diagnosis model analysis. Computers in Human Behavior, 122. https://doi.org/10.1016/j.chb.2021.106850.

Liza, K., \& Andriyanti, E. (2020). Digital Literacy Scale of English Pre-Service Teachers and Their Perceived Readiness toward the Application of Digital Technologies. Journal of Education and Learning (EduLearn), 14(1), 74-79. https://doi.org/10.11591/edulearn.v14i1.13925.

Maarop, A. H., \& Embi, M. A. (2016). Implementation of Blended Learning in Higher Learning Institutions: A Review of Literature. ResearchGate, 9(3), 41. https://doi.org/10.5539/ies.v9n3p4.

Masitoh, S. (2018). Blended Learning Berwawasan Literasi Digital Suatu Upaya Meningkatkan Kualitas Pembelajaran dan Membangun Generasi Emas 2045. Proceedings of the ICECRS, 1(3), 13-34. https://doi.org/10.21070/picecrs.v1i3.1377.

McDougall, J., \& Potter, J. (2019). Digital media learning in the third space. Media Practice and Education, 20(1), 1-11. https://doi.org/10.1080/25741136.2018.1511362.

Monitorir, R. (2020). Dampak Pandemi Covid-19 Terhadap Kepuasan Pembelajaran Jarak Jauh. Jurnal Inovasi Teknologi Pendidikan, 7(1). https://doi.org/10.21831/jitp.v7i1.32771.

Morze, N., Varchenko-Trotsenko, L., Terletska, T., \& Smyrnova-Trybulska, E. (2021). Implementation of adaptive learning at higher education institutions by means of Moodle LMS. Journal of Physics: Conference Series, 1840(1). https://doi.org/10.1088/1742-6596/1840/1/012062.

Nahdi, D. S., \& Jatisunda, M. G. (2020). Analisis Literasi Digital Calon Guru Sd Dalam Pembelajaran Berbasis Virtual Classroom Di Masa Pandemi Covid-19. Jurnal Cakrawala Pendas, 6(2), 116-123. https://doi.org/10.31949/jcp.v6i2.2133. 
Nasrullah, R., Aditya, W., Satya, T. I., Nento, M. N., Hanifah, N., Miftahussururi, \& Akbari, Q. S. (2017). Materi Pendukung Literasi Digital. In Kementerian Pendidikan dan Kebudayaan.

Norberg, A., Dziuban, C. D., \& Moskal, P. D. (2011). A time-based blended learning model. On the Horizon, 19(3). https://doi.org/10.1108/10748121111163913.

Park, H., Kim, H. S., \& Park, H. W. (2020). A Scientometric Study of Digital Literacy, ICT Literacy, Information Literacy, and Media Literacy. Journal of Data and Information Science. https://doi.org/10.2478/jdis-2021-0001.

Popkova, E. G., Ragulina, Y. V, \& Bogoviz, A. V. (2019). Industry 4.0: Industrial Revolution of the 21st Century. https://doi.org/10.1007/978-3-319-94310-7.

Purnama, S., Ulfah, M., Machali, I., Wibowo, A., \& Narmaditya, S. B. (2021). Does digital literacy in fl uence students ' online risk? Evidence from Covid-19. Heliyon, 7(6), 2-6. https://doi.org/10.1016/j.heliyon.2021.e07406.

Rafique, G. M., Mahmood, K., Warraich, N. F., \& Rehman, S. U. (2021). Readiness for Online Learning during COVID-19 pandemic: A survey of Pakistani LIS students. The $\begin{array}{llll}\text { Journal of Academic } & 102346 .\end{array}$ https://doi.org/10.1016/j.acalib.2021.102346.

Rastati, R. (2018). Media Literasi Bagi Digital Natives: Persektif Generasi Z Di Jakarta. Kwangsan: Jurnal Teknologi PendidikanJurnal Teknologi Pendidikan, 6(1). https://doi.org/10.31800/jtp.kw.v6n1.p60--73.

Rizal, R., Setiawan, W., \& Rusdiana, D. (2019). Digital literacy of preservice science teacher. Journal of Physics: Conference Series. https://doi.org/10.1088/17426596/1157/2/022058.

Rusdin, N. M. (2018). Teachers' Readiness in Implementing 21st Century Learning. International Journal of Academic Research in Business and Social Sciences, 8(4), 1271-1284. https://doi.org/10.6007//JARBSS/v8-i4/4270.

Sadaf, A., \& Johnson, B. L. (2017). Teachers' Beliefs About Integrating Digital Literacy Into Classroom Practice: An Investigation Based on the Theory of Planned Behavior. Journal of Digital Learning in Teacher Education, 33(4), 129-137. https://doi.org/10.1080/21532974.2017.1347534.

Sailer, M., Stadler, M., Schultz-Pernice, F., Franke, U., \& Schöffmann, C. (2021). Technology-related teaching skills and attitudes: Validation of a scenario-based selfassessment instrument for teachers. Computers in Human Behavior, 115. https://doi.org/10.1016/j.chb.2020.106625.

Sánchez-Cruzado, C., Santiago Campión, R., \& Sánchez-Compaña, M. T. (2021). Teacher digital literacy: The indisputable challenge after covid-19. Sustainability (Switzerland). https://doi.org/10.3390/su13041858.

Sari, R. P., Tusyantari, N. B., \& Suswandari, M. (2021). Dampak Pembelajaran Daring Bagi Siswa Sekolah Dasar Selama Covid-19. Prima Magistra: Jurnal IImiah Kependidikan, 2(1), 9-15. https://doi.org/10.37478/jpm.v2i1.732.

Shepherd, T., \& Henderson, M. (2019). Digital literacy in digital strategy. Canadian Journal of Communication. https://doi.org/10.22230/cjc.2019v44n2a3491.

Siregar, \& Manurung. (2020). Pengaruh Blended Learning terhadap Kreativitas Mahasiswa Calon Guru di Universitas Negeri Medan. Edumatika: Jurnal Riset Pendidikan Matematika, 3(1). https://doi.org/10.32939/ejrpm.v3i1.485.

Siripongdee, K., Pimdee, P., \& Tuntiwongwanich, S. (2020). A blended learning model with loT-based technology: effectively used when the COVID-19 pandemic? Journal for the Education of Gifted Young Scientists, 8(2), 905-917. https://doi.org/10.17478/jegys.698869.

Sukarno, \& Widdah, M. El. (2020). The Effect of Students' Metacognition and Digital Literacy in Virtual Lectures During The Covid-19 Pandemic on Achievement in The "Methods and Strategies on Physics Learning" Course. Jurnal Pendidikan IPA Indonesia, 9(4), 477-488. https://doi.org/10.15294/jpii.v9i4.25332. 
Suni Astini, N. K. (2020). Tantangan Dan Peluang Pemanfaatan Teknologi Informasi Dalam Pembelajaran Online Masa Covid-19. Cetta: Jurnal IImu Pendidikan, 3(2), 241-255. https://doi.org/10.37329/cetta.v3i2.452.

Sutisna, A. (2016). Pengembangan Model Pembelajaran Blended Learning pada Pendidikan Kesetaraan Program Paket $\mathrm{C}$ dalam Meningkatkan Kemandirian Belajar. JTP - Jurnal Teknologi Pendidikan, 18(3), 156-168. https://doi.org/10.21009/JTP1803.2.

Tang, Y. M., Chen, P. C., Law, K. M. Y., Wu, C. H., Lau, Y., Guan, J., He, D., \& Ho, G. T. S. (2021). Comparative analysis of Student's live online learning readiness during the coronavirus (COVID-19) pandemic in the higher education sector. Computers \& Education, 168, 104211. https://doi.org/10.1016/j.compedu.2021.104211.

Tomczyk, Ł. (2020). Skills in the area of digital safety as a key component of digital literacy among teachers. Education and Information Technologies. https://doi.org/10.1007/s10639-019-09980-6.

Unwin, T. (2019). The Future Use of Technology in Education and Learning in the Commonwealth. The Round Table, 108(4). https://doi.org/10.1080/00358533.2019.1634891.

Warden, C. A., Yi-Shun, W., Stanworth, J. O., \& Chen, J. F. (2020). Millennials' technology readiness and self-efficacy in online classes. Innovations in Education and Teaching International. https://doi.org/10.1080/14703297.2020.1798269.

Yigzaw, M., Tebekaw, Y., Kim, Y.-M., Kols, A., \& Ayalew, F. (2019). Comparing the effectiveness of a blended learning approach with a conventional learning approach for basic emergency obstetric and newborn care training in Ethiopia. Midwifery, 78. https://doi.org/10.1016/j.midw.2019.07.014.

Yildiz, E. P. (2020). Opinions of academicians on digital literacy: A phenomenology study. Cypriot Journal of Educational Sciences. .

Yilmaz, R. M., \& Goktas, Y. (2017). Using augmented reality technology in storytelling activities: examining elementary students' narrative skill and creativity. Virtual Reality, 21. https://doi.org/10.1007/s10055-016-0300-1.

Zain, I. M. (2017). The Collaborative Instructional Design System (CIDS): Visualizing the 21st Century Learning. Universal Journal of Educational Research, 5(12), 2259-2266. https://doi.org/10.13189/ujer.2017.051216. 